\title{
Relation of Alcohol to Road Accidents
}

\author{
B. R. HOPKINSON,* M.B., CH.B. ; G. M. WIDDOWSON, $\dagger$ B.SC., A.R.I.C.
}

Brit. med. F., 1964, 2, 1569-1570

The Special Committee on the Relation of Alcohol to Road Accidents of the British Medical Association (1960) concluded that a concentration of $50 \mathrm{mg}$. of alcohol in $100 \mathrm{ml}$. of blood of a person driving a motor vehicle was the highest that could be accepted as entirely consistent with the safety of other road users. This conclusion was reached after close investigation of many reports on the effect of alcohol on actual driving performance and of the large amount of statistical evidence on the relation of alcohol to road accidents. However, despite the importance of this subject and the wide interest it has generated, we are aware of only one study, that of Cassie and Allan (1961), in which the blood-alcohol levels of the drivers of vehicles involved in road traffic accidents in Great Britain were determined. This is probably due to the difficulty of obtaining blood samples in such cases. From the figures in that series we have calculated that $28 \%$ of the 239 road accident drivers studied had blood-alcohol levels above $50 \mathrm{mg} . / 100 \mathrm{ml}$. In view of this remarkable figure we felt that a further survey of a comparable nature was required.

\section{Method}

One of us (B.R.H.) had access to patients in the casualty department of the General Hospital, Birmingham, which in 1963 handled 69,193 new patients, 2,002 of whom (not all drivers) were involved in road traffic accidents. Between 15 February and 5 May 1964190 drivers of cars, commercial vehicles, motor-cycles, and pedal cycles involved in road traffic accidents were admitted to the department, and an attempt was made to obtain blood from all of these patients immediately on arrival. In fact, specimens were obtained from $140(74 \%)$.

It was impossible, as Cassie and Allan (1961) found, to determine as a control series the blood-alcohol levels of drivers not involved in an accident. Control series carried out in other countries by Holcomb (1938), Lucas et al. (1955), and Vamosi (1961) all showed that the percentage of drivers in the control group who had been drinking was much lower than the percentage of drivers in the accident group who had been drinking.

Blood alcohol was estimated by the Cavett method as described in Recognition of Intoxication (British Medical Association, 1954). Of the 140 blood-alcohol levels determined, 19 were from patients under 18 years of age (none of whom had any significant level of alcohol in their blood) and these were then excluded from the total.

We have chosen three levels of blood alcohol for study: $50 \mathrm{mg} . /$ $100 \mathrm{ml}$. and over, for the reason stated above ; $100 \mathrm{mg} . / 100 \mathrm{ml}$. and over, levels at which it has been shown that driving ability deterior-

* Casualty S.H.O., the General Hospital, Birmingham.

† Biochemist, the General Hospital, Birmingham. ates rapidly (British Medical Association, 1960) ; and $150 \mathrm{mg} . /$ $100 \mathrm{ml}$. and over, levels at which it was considered unsafe to drive a vehicle in any circumstances (British Medical Association, 1960).

\section{Results and Discussion}

Fig. 1 shows the distribution of the 190 road traffic accident drivers in our series plotted according to the hour of day in which their accident occurred.

There is an accident peak between 2200 and 2400 hours, a period when one would expect to find relatively little traffic on the road. When the 140 road-traffic-accident casualties in our series on whom blood-alcohol levels were determined

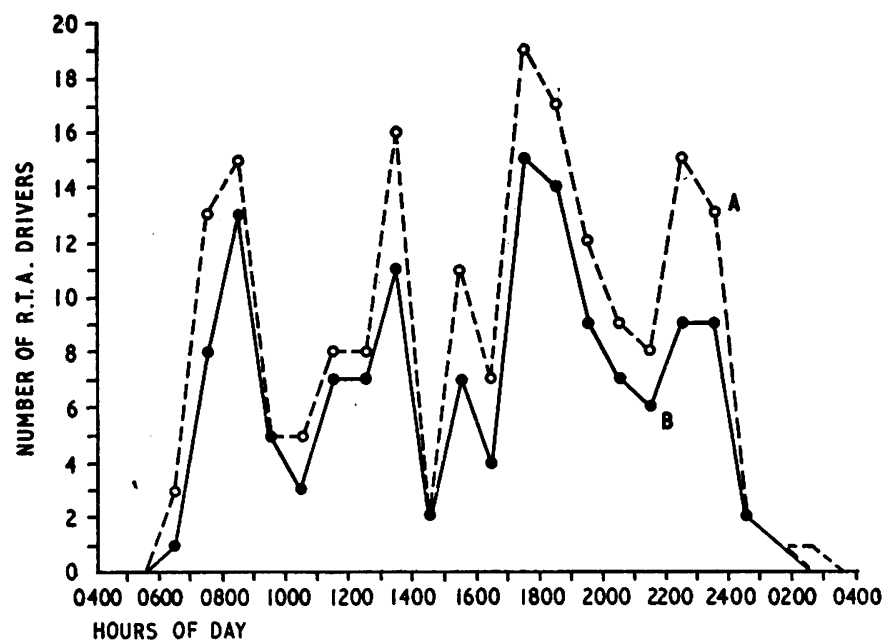

FIG. 1.-Summated R.T.A. drivers in our series distributed according to the hour of their accident. $A=$ Total hourly R.T.A. drivers. $B=$ Total hourly R.T.A. drivers subjected to blood-alcohol determination.

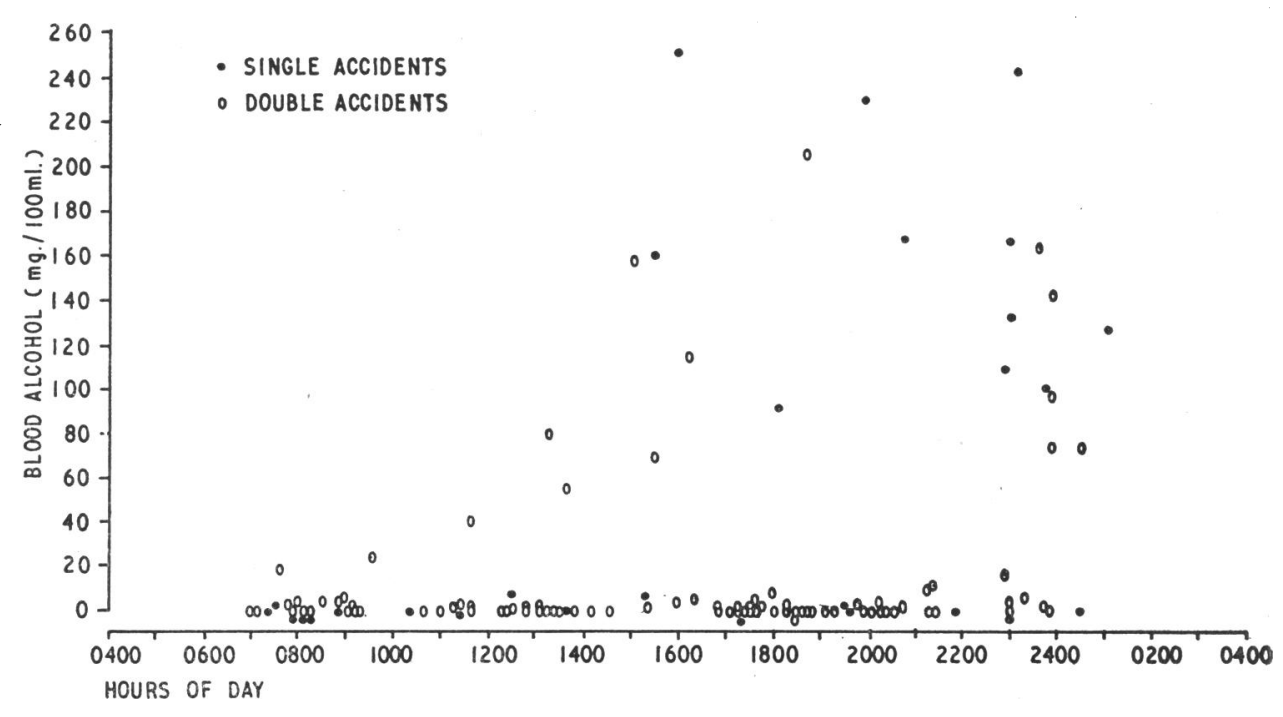

Fig. 2.-Blood-alcohol levels of the 121 R.T.A. drivers (18 years of age and over) distributed according to the hour of their accident. $=$ Drivers involved in accidents in which no other vehicle or pedestrian was concerned ("single accidents"). $O=$ Drivers involved in "double accidents." 
are plotted in the same way, an almost identical distribution is obtained. This shows that no selection was made according to the time of day of patients from whom samples were obtained.

Fig. 2 shows the blood-alcohol levels of the 121 road-trafficaccident drivers (aged 18 years and over) in our series according to the time of the accident in which they were involved. Between 2200 and 0200 hours there were 19 road-trafficaccident drivers (18 years of age and over) ; $11(58 \%)$ had blood alcohol levels above $50 \mathrm{mg} . / 100 \mathrm{ml} ., 8(42 \%)$ above $100 \mathrm{mg}$./ $100 \mathrm{ml} ., 3(16 \%)$ above $150 \mathrm{mg} . / 100 \mathrm{ml}$.

We divided the road-traffic-accident drivers in our series into two groups : those involved in accidents in which no other vehicle or pedestrian was concerned (" single accidents") and those involved in "double accidents." The number of drivers involved in single accidents with blood-alcohol levels under $50 \mathrm{mg} . / 100 \mathrm{ml}$., over $50 \mathrm{mg} . / 100 \mathrm{ml}$., over $100 \mathrm{mg} . / 100 \mathrm{ml}$., and over $150 \mathrm{mg} . / 100 \mathrm{ml}$. were 16 out of a total of $99(16 \%)$, 11 out of a total of $22(50 \%), 10$ out of a total of $15(66.6 \%)$, and 6 out of a total of $9(66.6 \%)$ respectively. These figures show a dramatic increase in the ratio of single to double accidents when the blood-alcohol level rises above $50 \mathrm{mg} . / 100$ $\mathrm{ml}$. These results agree with the findings of Jeffcoate (1958), who in a survey of $\mathbf{3 7 6}$ fatalities in road accidents showed that the driver who had been drinking tended to be involved relatively more frequently in single accidents, suggesting lack of attention or control.

In our series the overall proportion of drivers involved in road traffic acidents with blood-alcohol levels above $50 \mathrm{mg} . / 100$ $\mathrm{ml}$. irrespective of the time of day is $18.2 \%$. This figure agrees closely with the statistical survey of Jeffcoate (1958), who found that in $17 \%$ of all accidents it was known that someone involved had been drinking alcohol. This percentage is, however, somewhat lower than in the series of Cassie and Allan (1961).
It is clear from our results that a significant number of the drivers of vehicles involved in accidents have higher levels of alcohol in their blood than the British Medical Association Committee on Relation of Alcohol to Road Accidents regard as compatible with the ability to control a vehicle safely.

\section{Summary}

Blood-alcohol levels were determined on 121 drivers of vehicles involved in road traffic accidents in the Birmingham area who were admitted to a hospital casualty department between 15 February and 5 May 1964. The percentage of those drivers with blood-alcohol levels above $50 \mathrm{mg} . / 100 \mathrm{ml}$, irrespective of the time of day, was $18.2 \%$; between 2200 and 0200 hours $58 \%$ of drivers had blood-alcohol levels above $50 \mathrm{mg} . / 100 \mathrm{ml}$. The number of drivers involved in accidents in which no other vehicle or pedestrian was concerned ("singlc accidents ") was 16 out of a total of 99 (16\%) in the group with blood-alcohol levels below $50 \mathrm{mg} . / 100 \mathrm{ml}$. In the group with blood-alcohol levels above $50 \mathrm{mg} . / 100 \mathrm{ml}$. the proportion of "single accidents" increased to 11 out of a total of $22(50 \%)$.

We wish to thank Mr. A. B. Watson, Mr. J. C. Fulford, and Mr. M. H. M. Harrison for their co-operation and for access to patients under their care in the casualty department. We would especially thank the staff of the casualty department for their help in collecting blood samples. We are grateful to Dr. R. Gaddie for helpful criticism.

\section{REFERENCES}

British Medical Association (1954). Recognition of Intoxication. (1960). Relation of Alcohol to Road Accidents.

Cassie, A. B., and Allan, W. R. (1961). Brit. med. $\mathcal{F}$., 2, 1668.

Holcomb, R. L. (1938). F. Amer. med. Ass., 111, 1076.

Jeffcoate, G. O. (1958). Brit. ₹. Addict., 54, 81.

Lucas, G. H. W., et al. (1955). Proceedings of Second International Conference on Alcohol and Road Traffic, p. 139. Toronto.

Vamosi, M. (1961). Traffic Safety Res. Rev., 4, 8.

\title{
Serological Study of Respiratory Syncytial Virus Infections in Infancy and Childhood
}

\author{
P. S. GARDNER,* M.D., DIP.BACT. ; F. M. ELDERKIN, † M.B., B.S., M.R.C.P.ED., D.C.H. ; \\ A. H. WALL,* M.B., B.S., B.SC.
}

Brtt. med. J., 1964, 2, 1570-1573

The recent work of many workers both in the United States and in this country has shown how important respiratory syncytial virus (R.S.V.) is as an aetiological agent in the production of respiratory infection in young children (Chanock et al., 1961 ; McClelland et al., 1961; Holzel et al., 1963; Andrew and Gardner, 1963). This present study was undertaken to elucidate a number of outstanding questions. It was thought useful to investigate how early in an infant's life an antigenic response could be obtained to virus infection. Though a number of workers (Parrott et al., 1961; Sandiford and Spencer, 1962 ; Moss et al., 1963) have studied children with bronchiolitis and pneumonia, there was still very little information regarding the antibody response of infants under 3 months of age. Moreover, we wished to study the effect of the presence of maternal antibody on the antigenic responses. We wanted to see whether infection could take place in the presence of pre-existing antibody and also to see, by serological tech-

\footnotetext{
- Department of Microbiology, Royal Victoria Infirmary and University of Newcastle upon Tyne. t Department of Child Health, Royal Victoria Infirmary and University
of Newcastle upon Tyne.
}

niques, whether R.S.V. was an important aetiological agent every year. Finally we wished to investigate a report (Jensen, 1962) of a relationship between this virus and measles.

\section{Materials and Methods}

Over the last three winters (1961-2, 1962-3, 1963-4) suitably paired sera had been collected from children admitted with acute respiratory illnesses to paediatric units of a number of Newcastle hospitals and stored for studies of this kind. It is normal practice in these units for infants under 1 year of age to be barrier-nursed in cubicles to minimize the risk of crossinfection. Paired sera were taken at an interval which averaged 17 days, the first blood as soon as possible after admission and the second either before the child was discharged or at the first follow-up appointment. Sufficient blood could be obtained by heel stab, and the vast majority of specimens were obtained in this way. Material for virus isolation was taken from many of the cases, and this aspect of the investigation of the 1963-4 winter will be reported elsewhere. Our experience with the 